Bergman, I., and Loxley, R. (1970). Clinica Chimica Acta, 27, 347.

Falvo, K. A., and Bullough, P. G. (1973). Fournal of Bone and Foint Surgery, 55A, 275.

Follis, R. H. (1953). Bulletin of the fohns Hopkins Hospital, 93, 386.

Francis, M. J. O., and Macmillan, D. C. (1971). Biochimica et Biophysica Acta, 251, 236.

Francis, M. J. O., Smith, R., and Macmillan, D. C. (1973). Clinical Science, 44, 429 .

Grant, M. E., and Prockop, D. J. (1972). New England Fournal of Medicine, $83,194,242$, and 291 .

King, J. D., and Bobechko, W. P. (1971). Fournal of Bone and Foint Surgery, $53 \mathrm{~B}, 72$.

McKusick, V. (1972). Heritable Disorders of Connective Tissue, 4th edn. St. Louis, Mosby.
Miller, E. J. (1971). Biochemistry, 10, 1652.

Miller, E. J., Epstein, E. H., and Piez, K. A. (1971). Biochemical and Biophysical Research Communications, 42, 1024.

Robins, S. P., Shimokomaki, M., and Bailey, A. J. (1973). Biochemical Fournal, 131, 771 .

Seedorff, K. S. (1949). Osteogenesis Imperfecta: A Study of Clinical Features and Heredity based on 55 Danish Families comprising 180 Affected Individuals. Copenhagen, Ejnar Munksgaard.

Smith, R., and Francis, M. J. O. (1973). Quarterly fournal of Medicine, 42, 833.

Steven, F. S. (1966). Biochimica et Biophysica Acta, 130, 196.

Steven, F. S. (1970). Chemistry and Molecular Biology of the Intercellular Matrix, ed. E. A. Balazs, vol. I, p. 43. New York, Academic Press.

Tanzer, M. L. (1973). Science, 180, 561.

\title{
Observations on Drug Prescribing in Rheumatoid Arthritis
}

\author{
P. LEE S. J. AHOLA， D. GRENNAN， P. BROOKS, W. WATSON BUCHANAN
}

British Medical fournal, 1974, 1, 424-426

I firmly believe that if the whole material medica, as now used, could be sunk to the bottom of the sea, it would be all the better for mankind, and all the worse for the fishes.-OLIVER WeNDALl Holme. ${ }^{1}$

\section{Summary}

A total of 125 patients with rheumatoid arthritis were investigated about their drug therapy before referral to a specialist centre. Most referrals were from general practitioners. Only 47 of the patients had received salicylates as the first drug and 18 had never had them at all. Soluble aspirin was the preparation of salicylates most frequently prescribed (for 63 patients). Only 60 patients had been given an adequate dose and only 62 an adequate course of treatment with salicylates. In 28 patients salicylates had been stopped on account of side efiects. About one-third of the patients had been prescribed oral corticosteroids.

The referral letters were poor in giving details of past and present drug therapy, and there were serious omissions in reporting of previous side effects.

Seventy-five general practitioners were asked to rate several currently marketed antirheumatic drugs in terms of effectiveness. Though prednisolone $15 \mathrm{mg}$ daily ranked higher than aspirin $4 \mathrm{~g}$ daily the difference was not significant. The study shows the inadequacies of drug prescribing for rheumatoid arthritis in the Glasgow area.

\section{Introduction}

Many analgesic and anti-inflammatory drugs may now be prescribed to relieve pain in rheumatoid arthritis. Nevertheless, the "sheet-anchor" of treatment is still salicylates. ${ }^{2-5} \mathrm{We}$ have found that many patients referred for consultation have not received salicylates as their first drug and many have never received them at all. We have therefore reviewed drug treatment in new referrals to this clinic and the information regarding drug

Centre for Rheumatic Diseases and University Department of Medicine, Glasgow Royal Infirmary, Glasgow G4 OEH

P. LEE, M.B., M.R.A.C.P., Senior Registrar in Rheumatology

S. J. AHOLA, M.D., Registrar

D. J. ARENNAN, M.B., M.R.C.P., Registrar

D. GRENNAN, M.B., M.R.C.P., Registrar

P. BROOKS, M.B., M.R.A.C.P., Registrar
W. WATSON BUCHANAN, M.D., F.R.C.P., Professor of Medicine therapy given in the referral letter. The results indicate an unsatisfactory state of drug prescribing in patients with rheumatoid arthritis in Glasgow.

\section{Patients and Methods}

We interviewed 125 patients, who were seen consecutively by one doctor, about their drug therapy before they were referred to the centre. The mean age of the patients was 50.6 \pm S.D. 15.6 years (range 13 to 82 years) and 93 were female. All had "definite" or "classical" rheumatoid arthritis according to the diagnostic criteria of the American Rheumatism Association." The mean duration of arthritis was $7 \cdot 2 \pm 7 \cdot 3$ years, with a range from one month to 31 years.

Each patient was questioned about the first drug prescribed for his arthritis, its dose and duration, and whether it gave rise to side effects; similar details were obtained for all other drugs prescribed. When the patient was uncertain about what drug he had been given he was asked to identify it from a display of available antirheumatic agents. When doubt still existed a letter was sent to the family doctor to verify the preparation given. In 13 patients the first drug prescribed could not be ascertained with certainty, and these patients were not included in the study. We also noted the source of patient referral and whether the accompanying letter mentioned previous and current drug therapy and its dosage-also whether side effects had resulted.

We recorded the preparation of salicylate which had been prescribed and whether salicylates were prescribed in proper dosage-that is, $3 \mathrm{~g}$ or more per day-and whether this was given a proper trial-three months or more. We noted also the reason for discontinuing salicylate therapy, any self-medication of analgesics, and the preparation and dosage of corticosteroid therapy.

To determine opinions on the effectiveness of available antirheumatic drugs we sent a questionnaire to 75 general practitioners in Glasgow chosen at random from the General Medical Service list of medical practitioners. They were asked to rate the effectiveness of a number of preparations on a fivepoint scale: totally ineffective 1 , ineffective 2 , moderately effective 3 , effective 4 , and highly effective 5 (see table VI). Forty-nine replies were received. A further 250 general practitioners were asked whether they approved of a proposed standard regimen of drug treatment consisting of initial treatment with salicylates $3 \cdot 5-4 \mathrm{~g}$ daily. Should the patient fail to tolerate or respond to salicylates indomethacin up to $150 \mathrm{mg}$ daily, benorylate $10 \mathrm{ml}$ twice a day, or phenylbutazone $300 \mathrm{mg}$ daily could be given. If this treatment failed then gold or penicillamine, corticosteroids, or immunosuppressive agents might be given but only in consultation with a rheumatologist. As adjuncts to treatment we recommended ibuprofen $1,200 \mathrm{mg}$ 
daily, Distalgesic (dextropropoxyphene $32.5 \mathrm{mg}$ and paracetamol $325 \mathrm{mg}$ ), or mefenamic acid $1,500 \mathrm{mg}$ daily.

\section{Results}

Most patients were referred by their general practitioner, 69 coming from this source, while 22 were referred by a consultant physician, 14 by a consultant surgeon, and 20 by a medical registrar. Only 47 patients had first received salicylates and 18 patients had not received them at all before they were referred for consultation (table I). The most popular type of aspirin prescribed was soluble aspirin (table II). Only 60 patients out of the 94 who were given salicylates were prescribed what we considered to be an adequate dose of salicylates- $3 \mathrm{~g}$ per day or more-and only 62 had had an adequate course of treatmentthree months or longer. Therapy had had to be discontinued on account of side effects in 28 patients-in 21 because of dyspepsia. Ten patients had discontinued salicylate therapy on advice from their family doctor that the drug was dangerous. Two of these patients, however, had had duodenal ulceration (table III).

The most frequently used oral preparation for systemic corticosteroid therapy was prednisolone (21 patients), and

TABLE I-Initial Treatment and Other Drugs Prescribed for 112 Patients with Rheumatoid Arthritis before Referral to Specialist Centre

\begin{tabular}{|c|c|c|c|c|c|}
\hline & & & & First Drug & Other Drugs \\
\hline & & & & No. & No. \\
\hline 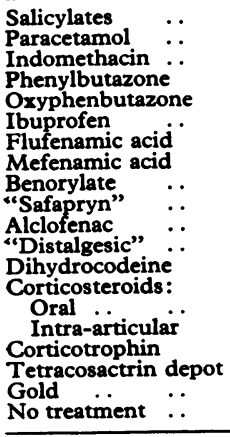 & 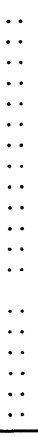 & 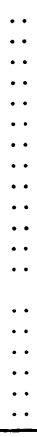 & $\begin{array}{l}\ldots \\
\because \\
\because \\
\because \\
\because \\
\because \\
\because \\
\because \\
\because \\
\cdots \\
\because \\
\because \\
\cdots \\
\cdots\end{array}$ & $\begin{array}{r}47 \\
3 \\
22 \\
12 \\
1 \\
8\end{array}$ & $\begin{array}{r}94 \\
44 \\
83 \\
43 \\
4 \\
40 \\
6 \\
3 \\
2 \\
2 \\
3 \\
4 \\
5\end{array}$ \\
\hline Total & & & & $113^{*}$ & \\
\hline
\end{tabular}

* One patient started on both salicylates and indomethacin.

TABLE II-Types of Aspirin Prescribed in 94 Patients with Rheumatoid Arthritis Treated with Salicylates

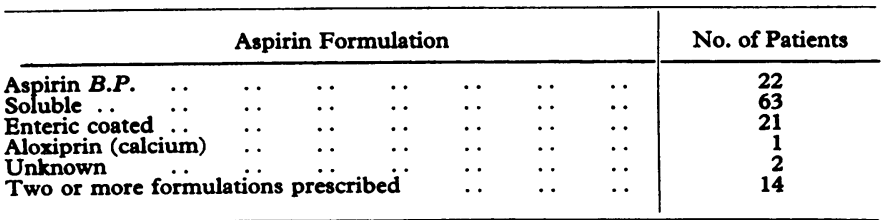

TABLE III-Dosage, Duration, and Reasons for Stopping Therapy in 94 Rheumatoid Arthritic Patients Treated with Salicylates

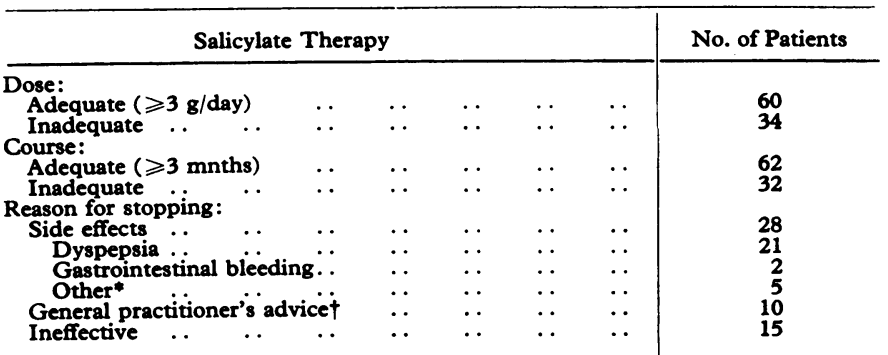

*This comprised two patients with rash, one with dizziness, one with tinnitus, and

one with constipation.
These included two patients with duodenal ulceration. tetracosactrin depot (six patients) was more commonly prescribed than natural corticotrophin (four patients; table IV). Excessive dosage of oral corticosteroid therapy-that is, more than $10 \mathrm{mg}$ prednisolone equivalent-had been prescribed in 19 patients.

TABle IV-Systemic Corticosteroid Therapy in 48 Patients with Rheumatoid Arthritis

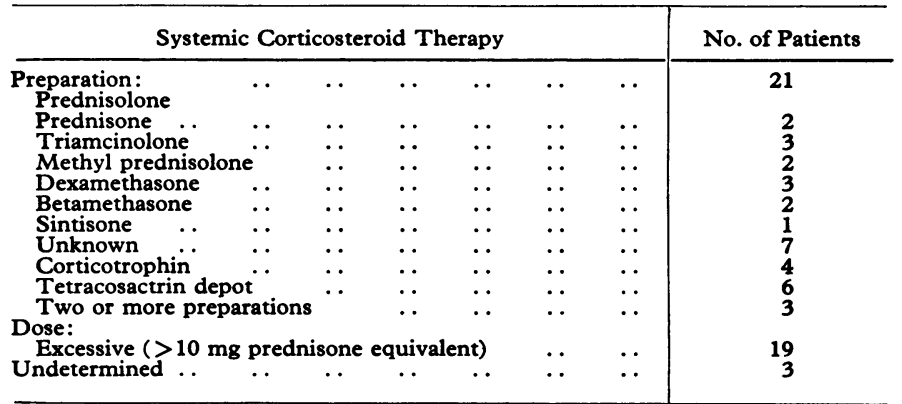

Of 639 drugs which had been prescribed only 107 were mentioned in the referral letter (table V). Fifty-one patients had suffered between them 85 definite side effects, but only three side effects were recorded in the letter. Four serious side effects were omitted from the letters: haematemesis on aspirin; severe depression on ibuprofen; agranulocytosis on phenylbutazone; and a peptic ulcer on phenylbutazone. Dosage of past drug therapy was mentioned for only 15 patients in 22 of the prescribed drugs. The details of current therapy showed much the same pattern of documentation. Of 160 drugs currently being prescribed only 56 were mentioned in the letter. The dosage of these drugs was recorded only in 20 instances for 17 patients, and only four out of 19 side effects were mentioned.

TABLE v-Past and Current Antirheumatic Drug Therapy in 112 Patients mentioned by the Patients and their referring Doctors. Figures in Parentheses are Numbers of Patients

\begin{tabular}{|c|c|c|c|}
\hline & & $\begin{array}{c}\text { Mention by } \\
\text { Patients }\end{array}$ & $\begin{array}{c}\text { Mention by } \\
\text { Referring Doctor }\end{array}$ \\
\hline $\begin{array}{l}\text { Past drug therapy: } \\
\text { No. of drugs } \\
\text { Mean no. of drugs per patient } \\
\text { No. of dosages } \ldots \\
\text { No. of side effects } \\
\text { Present drug therapy: } \\
\text { No. of drugs } \\
\text { Mean no. of drugs per patient } \\
\begin{array}{l}\text { No. of dosages } \\
\text { No. of side effects }\end{array}\end{array}$ & 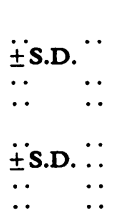 & $\begin{array}{l}369 \\
3 \cdot 0 \pm 1 \cdot 7 \\
85(51) \\
160 \\
1 \cdot 3 \pm 0 \cdot 7 \\
19(18)\end{array}$ & $\begin{array}{r}107(54) \\
22(15) \\
3(2) \\
56(46) \\
20(17) \\
4(4)\end{array}$ \\
\hline
\end{tabular}
Three patients were never prescribed antirheumatic drugs and seven were receiving
no antirheumatic drugs at the time of study.

All the $\mathbf{4 9}$ general practitioners replying to our questionnaire considered that all the drugs were superior to placebo (table VI). Surprisingly, however, though prednisone in a daily dose of $15 \mathrm{mg}$ was rated higher than aspirin $4 \mathrm{~g}$ per day the difference was not statistically significant.

The results of a questionnaire sent to 250 general practitioners in Glasgow asking about their prescribing habits showed that 25 of them did not consider salicylates as the drug of first choice. The reason was that patients in practice fail to tolerate high-dose salicylate therapy and most patients find low doses of salicylates ineffective. Of these 25 practitioners 20 first prescribed ibuprofen or indomethacin, two prescribed phenylbutazone, and three prescribed oral corticosteroids.

\section{Discussion}

This study was designed to obtain information about prescribing practices in Glasgow for patients with rheumatoid 
TABLE VI-Effectiveness of Various Antirheumatic Drugs according to Opinions of 49 General Practitioners. Mean Effectiveness calculated on Five-point Scale (see Text)

\begin{tabular}{|c|c|c|c|c|c|}
\hline \multirow{2}{*}{ Drug } & \multirow{2}{*}{ Dose/Day } & \multirow{2}{*}{$\begin{array}{l}\text { Effectiveness } \\
\text { (Mean } \pm \text { S.E. } \\
\text { of Mean) }\end{array}$} & \multicolumn{3}{|c|}{ Statistical Significance } \\
\hline & & & Comparison & $t$ & $\mathbf{p}$ \\
\hline 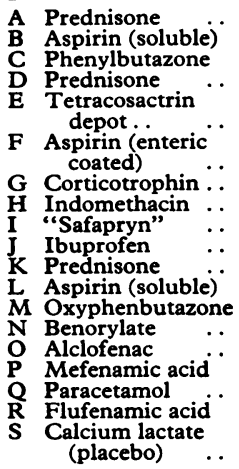 & $\begin{aligned} 15 \mathrm{mg} \\
4 \mathrm{~g} \\
300 \mathrm{mg} \\
10 \mathrm{mg} \\
0.5^{*} \mathrm{mg} \\
4 \mathrm{~g} \\
100 \mathrm{mg} \\
12 \mathrm{tabs} \\
1,200 \mathrm{mg} \\
5 \mathrm{mg} \\
2 \mathrm{~g} \\
300 \mathrm{mg} \\
20 \mathrm{ml} \\
3 \mathrm{~g} \\
1,500 \mathrm{mg} \\
4 \mathrm{~g} \\
600 \mathrm{mg} \\
4 \mathrm{tabs}\end{aligned}$ & 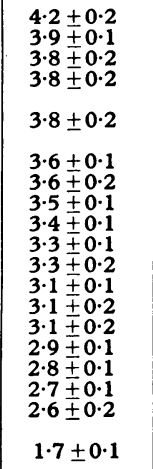 & 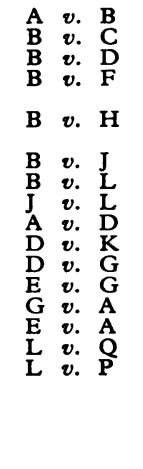 & $\begin{array}{l}1.04 \\
0.73 \\
0.59 \\
2.67 \\
\\
2.51 \\
3.86 \\
9.12 \\
1.20 \\
3.99 \\
5.50 \\
1.67 \\
1.46 \\
0.97 \\
0.34 \\
3.00 \\
2.10\end{array}$ & $\begin{array}{l}\text { N.S. } \\
\text { N.S. } \\
\text { N.S. } \\
<0.01 \\
<0.01 \\
<0.0005 \\
<0.0005 \\
\text { N.S. } \\
<0.0005 \\
<0.0005 \\
\text { N.S. } \\
\text { N.S. } \\
\text { N.S. } \\
\text { N.S. } \\
<0.0025 \\
<0.025\end{array}$ \\
\hline
\end{tabular}

N.S. $=$ Not significant

* $=$ Twice weekly dose

arthritis. The study was retrospective and, as such, suffers from the limitations of this type of investigation. Nevertheless, the results do highlight several disturbing features.

Despite the acceptance of salicylates as the drug of choice in rheumatoid arthritis, ${ }^{2-10}$ only 47 patients were first treated with this drug. In addition 18 patients had never received salicylate therapy at any time during their illness. Of those who had had salicylate therapy about one-third had not received an adequate course of treatment, in terms either of dosage or of duration of therapy. Their family doctors had told $10 \%$ of patients to discontinue treatment with salicylates because they considered them dangerous. In a poll of over 5,000 doctors in the United States only a quarter prescribed salicylates as the drug of first choice in rheumatoid arthritis. ${ }^{11}$

The question arises Why do some family doctors not prescribe salicylates to their patients with rheumatoid arthritis? The answer may be that they consider that salicylates in high doses cause side effects whereas in low doses they are inadequate to relieve pain. In the 250 replies to our questionnaire 25 family doctors gave this as their reason for not prescribing salicylates as the drug of first choice. It is difficult to fault this answer since 28 patients in the present study had to discontinue salicylates because of side eifects, mostly dyspepsia. We do not, however, agree with the two family doctors who considered phenylbutazone or the three doctors who preferred oral corticosteroids as the drug of first choice. Clearly several family doctors in Glasgow prescribe phenylbutazone and oral corticosteroids as the drugs of first choice in treating patients with rheumatoid arthritis (see table I). It would be interesting to know their views on the potential toxicity of these particular antirheumatic agents.

The high percentage of patients in this study who had been treated with systemic corticosteroids is surprising and runs contrary to present recommendations to use corticosteroid therapy as infrequently as possible. Many of the patients had severe rheumatoid arthritis, and it could be argued that corticosteroid therapy was justified but for the fact that most patients had not had a careful and unhurried trial of non-steroidal analgesic drugs. A particular criticism is that 19 of those given oral corticosteroids received doses over $10 \mathrm{mg}$ prednisolone per day or equivalent. In view of the popularity of corticosteroid therapy it is interesting that the doctors assessed the mean analgesic effect of $15 \mathrm{mg}$ prednisolone as not being more effective than $4 \mathrm{~g}$ of soluble aspirin.

Only 18 patients in the present study admitted to selfmedication, mostly as salicylates; only two patients said they were taking phenacetin-containing mixtures. It is impossible to know how accurate these data are, and they are probably an underestimate. Murray ${ }^{12}$ found that 128 of 740 Glasgow citizens admitted to taking analgesics at least weekly, and most of these did so without reference to a doctor. Furthermore, the incidence of analgesic nephropathy in the West of Scotland is four times greater than that found in England and Wales. ${ }^{13}$

The referring doctor's recording of past and present drug therapy can hardly be described as adequate. The letters, however, were reasonably adequate about the patient's symptoms, past and family histories, physical findings, and results of laboratory data. Thus, for example, one doctor's letter which ran to two pages of typescript gave every detail of the patient's illness except what drugs had been and were being prescribed. This patient had had a haematemesis from a duodenal ulcer while receiving phenylbutazone. Hence the importance of drug therapy in the management of patients still lags far behind in most doctors' thoughts. Interestingly, there was no difference between details of drug therapy in letters from hospital doctors and family doctors, though letters from surgical colleagues lagged far behind in this matter. Clearly more education is needed in this important aspect of medical care.

Regional differences in drug prescribing have been noted both in general ${ }^{14}$ and in rheumatic disease. ${ }^{15}$ In our region there is, for example, little gold prescribed for rheumatoid arthritis, though in several areas in the United States it is extremely popular. It remains to be seen whether the inadequacies of drug prescribing which we have observed in Glasgow are similar in other parts of the world.

We thank the Arthritis and Rheumatism Council for Research in Great Britain for financial support.

Request for reprints should be sent to: Dr. Peter Lee, Centre for Rheumatic Diseases, 35 Baird Street, Glasgow G4 0EH.

\section{References}

${ }^{1}$ Holmes, O. W., Currents and Counter-currents in Medical Science, Boston, Ticknor and Fields, 1860.

2 An Introduction to Clinical Rheumatology, ed. M. Mason and H. L. F. Currey, London, Pitman, 1970.

3 Boyle, J. A., and Buchanan, W. W., Clinical Rheumatology, Oxford. Blackwell Scientific Publications, 1971.

${ }^{4}$ Dick, W. C., Clinical Rheumatology, Edinburgh, Livingstone, 1972.

5 Arthritis and Allied Conditions, ed. J. L. Hollander and D. J. McCarty, jun., 8th edn., Philadelphia, Lea and Febiger, 1972

- Ropes, M. W., Bennett, G. A., Cobb, S., Jacox, R., and Jessar, R., Annals of the Rheumatic Diseases, 1959, 18, 49.

7 Smyth, C. J., Postgraduate Medicine, 1968, 44, 77

8 Ansell, B. M., Prescribers' Fournal, 1969, 8, 120.

Nuki, G., and Dick, W. C., British fournal of Hospital Medicine, 1969, 2, 1962 .

${ }_{11}$ Hislop, I., New Ethicals, 1972, May, p. 142.

11 Poll on Medical Practice; Rheumatoid Arthritis (1966), Modern Medicine, 1966,34 , No. 16,75

12 Murray, R. M., Scottish Medical Xournal, 1972, 17, 393.

13 Murray, R. M., Health Bulletin, (in press).

14 Dunlop, D., and Inch, R. S., British Medical fournal, 1972, 3, 749.

15 Mizushima, Y., Acta Rheumatologica Scandinavica, 1966, 12, 210. 